\title{
Ten-year experience of an invasive cardiology centre with out-of-hospital cardiac arrest patients admitted for urgent coronary angiography
}

\author{
Aleksander Zeliaś ${ }^{1}$, Janina Stępińska², Janusz Andres³ ${ }^{3}$ Aleksander Trąbka-Zawicki ${ }^{1}$, Jerzy Sadowski", \\ Krzysztof Żmudka' \\ ${ }^{1}$ Clinic of Interventional Cardiology, Institute of Cardiology, Jagiellonian University Medical College, \\ John Paul II Hospital, Krakow, Poland \\ ${ }^{2}$ Department of Cardiac Intensive Care, Institute of Cardiology, Warsaw, Poland \\ ${ }^{3}$ Department of Anaesthesiology and Intensive Care, Jagiellonian University Medical College, Krakow, Poland \\ ${ }^{4}$ Department of Cardiovascular Surgery and Transplantology, Jagiellonian University Medical College, John Paul II Hospital, Krakow, Poland
}

\begin{abstract}
A b stract
Background and aim: The aim of the study was to evaluate survival and neurological function of out-of-hospital cardiac arrest (OHCA) patients admitted for urgent coronary angiography (UCA) with a view to percutaneous coronary intervention (PCI).

Methods: Hospital records of OHCA patients admitted to an invasive cardiology centre (providing $24 \mathrm{~h}$ a day/7 days a week service) in 2000-2010 were reviewed retrospectively, and similar data collected in 2011 were reviewed prospectively. Reports from the pre-hospital phase from emergency medical services (EMS) in Krakow were also analysed. Long-term follow-up data were collected by retrieving records from other hospitals (for patients transferred after UCA/PCI) and by phone calls to patients or their relatives.

Results: In 2000-2011, 405 OHCA patients were admitted for UCA/PCI. Most (78\%) had ventricular fibrillation (VF) or ventricular tachycardia (VT) as the primary mechanism of cardiac arrest (asystole: $13 \%$, pulseless electrical activity: 3\%, unknown: $6 \%$ ). The mean patient age was 61 (range 20-85) years, and 81\% were males. On admission, about 70\% of patients were unconscious and 11\% were in cardiogenic shock. The mean resuscitation time (time to return of spontaneous circulation [ROSC]) was 26.7 (range 1-126) min. ST-T changes seen in an electrocardiogram recorded after ROSC included ST elevation and depression in $52 \%$ of cases, only ST depression in $21 \%$ of cases, only ST elevation in $17 \%$ of cases, unspecific changes (due to intraventricular conduction disturbances) in $7 \%$ of cases, negative $\mathrm{T}$ waves in $3 \%$ of cases, and no changes in $0.5 \%$ of cases. Coronary angiography revealed acute coronary occlusion in $48 \%$ of cases, critical coronary stenosis (> 90\%) in $26 \%$ of cases, other significant coronary lesions (> 50\% stenosis) in $15 \%$ of cases, and non-significant lesions in $11 \%$ of cases. An acute coronary syndrome (ACS) was diagnosed in $82 \%$ of patients $(75 \%$ STEMI, 25\% NSTEMI), and other cardiac cause (mostly ischaemic cardiomyopathy) was identified in 13\% of patients. Among OHCA patients diagnosed with ACS, $\mathrm{PCl}$ was performed in $90 \%$ and additional $4 \%$ underwent coronary artery bypass grafting. Overall success rate of $\mathrm{PCl}$, defined as TIMI 3 flow plus residual stenosis $<50 \%$ and resolution of $\mathrm{ST}$ elevation after $\mathrm{PCl}$ by $>30 \%$, was $70 \%$. Survival to hospital discharge in the entire group of OHCA patients was $63 \%$ and 30-day survival with good neurological outcomes (defined as Cerebral Performance Category 1 or 2) was $49 \%$. Among patients who were initially unconscious, those figures were $52 \%$ and $33 \%$, respectively. During long-term follow-up (up to 12 years), $49 \%$ of patients were alive and $42 \%$ had good neurological function ( $87 \%$ of those who survived). In multivariate analysis, independent predictors of survival with good neurological outcomes were preserved consciousness on admission, absence of shock, cardiac arrest witnessed by medical personnel, VF/VT as a primary mechanism of cardiac arrest, and preserved renal function. Successful PCl predicted survival until hospital discharge only when the neurological status of the patients was not taken into account.

Conclusions: The most important cause of OHCA is coronary artery disease, in particular ACS. UCA and PCI seem to be important elements of appropriate post-resuscitation care because such treatment could improve survival but it is still unclear whether $\mathrm{PCI}$ might influence neurological outcomes as well.
\end{abstract}

Key words: out-of-hospital cardiac arrest, coronary angiography, percutaneous coronary intervention, survival, neurological outcome

Kardiol Pol 2014; 72, 8: 687-699

\section{Address for correspondence:}

Aleksander Zeliaś, MD, PhD, Clinic of Interventional Cardiology, Institute of Cardiology, Jagiellonian University Medical College, John Paul II Hospital, ul. Prądnicka 80, 31-202 Kraków, Poland, e-mail: aazelias@gmail.com Received: 02.11.2013 Accepted: 13.02.2014

Copyright (C) Polskie Towarzystwo Kardiologiczne

Available as AoP: 01.04.2014 


\section{INTRODUCTION}

Cardiac arrest is a major cause of mortality in developed countries [1]. The incidence of out-of-hospital cardiac arrest (OHCA) in the European population has been estimated at about 40 per 100,000 per year [2]. Coronary artery disease is thought to be responsible for up to $80 \%$ of OHCA cases [3]. Survival after OHCA remains very low at about 10\% [4]. Overall patient survival following cardiac arrest depends on all components of the chain of survival, including appropriate post-resuscitation care (Fig. 1) [5]. In addition to mild therapeutic hypothermia, an essential component of the latter is now early coronary angiography (CAG) and interventional treatment [6]. It has been suggested that urgent coronary intervention in unconscious patients after cardiac arrest may improve survival [7]. In the current European Society of Cardiology (ESC) guidelines, invasive CAG and interventional treatment are recommended in patients with ST segment elevation myocardial infarction (STEMI) complicated by cardiac arrest (class of recommendation I, level of evidence B), and such treatment should be considered in patients after cardiac arrest presenting without ST elevation but with suspected myocardial infarction $(\mathrm{MI})$ as the cause of cardiac arrest (class of recommendation lla, level of evidence B) (Fig. 1) [8].

The aim of this study was to evaluate treatment outcomes in OHCA patients with likely coronary aetiology of the event who were admitted for urgent invasive CAG. The primary endpoint was survival with good neurological outcome at discharge. Good neurological outcome was defined as survival until discharge with no or only mild neurological deficits (allowing independent functioning) - Cerebral Performance Category 1-2 [9]. A secondary endpoint was survival until discharge regardless of the neurological outcome (Table 1).

\section{METHODS}

We studied consecutive OHCA patients with likely cardiac aetiology admitted for urgent invasive CAG to the Centre of Invasive Cardiovascular Treatment (CILChSiN, Centrum Interwencyjnego Leczenia Chorób Serca i Naczyń). The decision to admit an OHCA patient for invasive CAG was made by a physician on duty in the cardiac catheterisation laboratory, and it was based on individual clinical judgment of the likelihood that cardiac arrest was due to an acute coronary syndrome (ACS).

Data on patients admitted following a cardiac arrest from January 2000 till August 2010 were collected retrospectively based on available medical records and digitally stored CAGs. In addition, when a patient was later transferred to another hospital in Krakow, respective medical records of these patients were retrieved from hospital archives to determine further clinical course, patient destination at final discharge, and neurological condition. Data regarding circumstances of cardiac arrest and details of resuscitation were obtained from emergency medical services (EMS) in Krakow. In addition, data regarding long-term survival of residents of the Malopolskie voivodship were obtained from the Universal Electronic System for Registration of the Population (PESEL, Powszechny Elektroniczny System Ewidencji Ludności) database. Since September 2010, all patient-related data were collected prospectively. Details regarding cardiac arrest were collected based on interviews with EMS team leaders involved in the resuscitation, EMS dispatchers, and patient family members. For the purpose of prospective data collection, we also developed a special post-cardiac arrest patient form intended to be filled by physicians on duty who admitted such patients for invasive CAG (Fig. 2).

During the next stage of the study (October 2011 till January 2012), we contacted patients or their families by phone to ascertain current neurological status of the patient and occurrence of long-term outcomes including reccurent cardiac arrest, cardiovascular death, $\mathrm{MI}$, stroke, and implantation of an implantable cardioverter-defibrillator (ICD) for secondary prevention of sudden cardiac death (SCD).

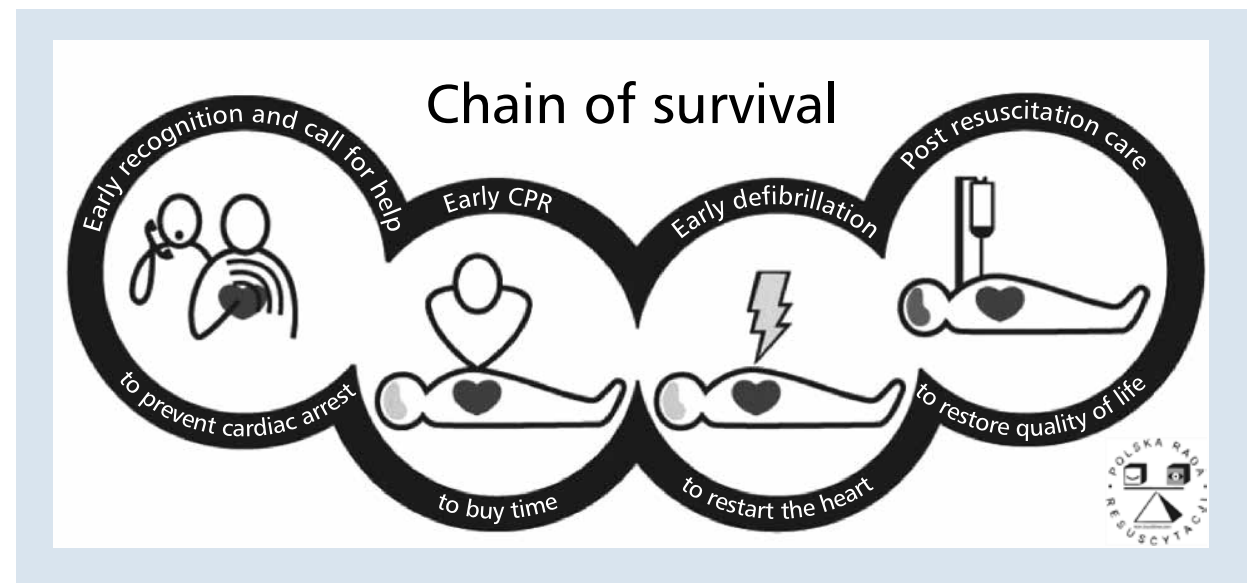

Figure 1. Chain of survival, CPR - cardiopulmonary resuscitation 
Table 1. Cerebral Performance Category (CPC) scale

\begin{tabular}{|c|c|}
\hline Category & Description \\
\hline CPC 1 & $\begin{array}{l}\text { Good cerebral performance: conscious, alert, able to work, might have mild neurological or psychological deficit } \\
\text { (mild dysphasia, mild hemiparesis or mild cranial nerve disturbances). }\end{array}$ \\
\hline CPC 2 & $\begin{array}{l}\text { Moderate cerebral disability: conscious, sufficient cerebral function for independent activities of daily life (getting dressed, } \\
\text { using public transport, preparing meals), able to work in sheltered environment. Hemiparesis, epilepsy, ataxia, dysarthria, } \\
\text { dysphasia, and permanent memory or mental deficits may be present. }\end{array}$ \\
\hline CPC 3 & $\begin{array}{l}\text { Severe cerebral disability: conscious but with varyingly limited ability to interact with environment, dependent on others for } \\
\text { daily support because of impaired brain function (in long-term care facility or at home). Ranges from ambulatory patients } \\
\text { but with severe memory deficits or dementia to those paralysed, bedridden and able to communicate with the eyes only } \\
\text { (locked-in syndrome). }\end{array}$ \\
\hline CPC 4 & $\begin{array}{l}\text { Coma or vegetative state: cerebral unresponsiveness, unawareness, without interaction with environment even if may show } \\
\text { sleep/awake cycles and open eyes spontaneously; does not fulfil brain death criteria. }\end{array}$ \\
\hline CPC 5 & Brain death, apnoea, areflexia, electroencephalography silence. \\
\hline
\end{tabular}

Severity of coronary atherosclerosis was evaluated based on the number of vessels with significant lesions (> 50\% stenosis) and additionally using the Syntax score [10]. Coronary angioplasty success was defined as TIMI 3 flow in the culprit artery following coronary intervention [11], less than $50 \%$ residual stenosis, and resolution of ST elevation (in STEMI patients) by at least 30\% in an electrocardiogram (ECG) recorded immediately after the procedure.

The study was approved by the Bioethics Committee at the Jagiellonian University (approval No. KBET/210/B2010 of November 25, 2010).

\section{Statistical analysis}

Categorical variables were reported as numbers and percentages of items in each class. Quantitative variables were reported as arithmetic means, medians, and standard deviations. We then evaluated the effect of studied variables on the primary endpoint of the study. For categorical variables, rates of the primary endpoint for different variable categories were shown using contingency tables, and statistical significance of the differences was evaluated using the $\chi^{2}$ test. Differences between mean values of quantitative variables in patients groups defined by the presence or absence of the primary endpoint were evaluated using the Student t test for normally distributed variables and the Mann-Whitney $U$ test for non-normally distributed variables. Multivariate analysis was performed using the logistic regression method. Significance was set at the alpha level of 0.05. Statistical analyses were performed using the Statistica PL 10 software (Statsoft).

\section{RESULTS}

Overall, we studied 405 OHCA patients, including 340 patients identified retrospectively and 65 patients evaluated prospectively. The mean annual number of such patients admitted to CILChSiN was about 36 (Fig. 3).
Patients after cardiac arrest constituted only a small proportion (about $2 \%$ ) of all acutely admitted patients. The mean age was 61 years, $81 \%$ of patients were men, and ventricular fibrillation (VF) or ventricular tachycardia (VT) was identified as the primary mechanism of cardiac arrest in $78 \%$ of patients. In $44 \%$ of patients, cardiac arrest was witnessed by healthcare personnel (which resulted in immediate initiation of advanced life support), and the mean time from cardiac arrest to the return of spontaneous circulation (ROSC) was $26.7 \mathrm{~min}$. On admission to CILChSiN, two thirds of patients were unconscious, and 1 in 10 patients was in cardiogenic shock (Table 2).

ST segment changes seen in an ECG recorded after ROSC are shown in Figure 4. The most commonly identified changes were ST segment elevation or ST elevation and depression (Fig. 4).

CAG showed an acute vessel occlusion in $48 \%$ of patients, a critical stenosis (> 90\%) in $26 \%$ of patients, and other significant coronary atherosclerotic lesions (50-90\% stenosis or chronic occlusion) in $15 \%$ of patients. In only $11 \%$ of patients, no significant coronary lesions were found in CAG performed after cardiac arrest (Fig. 5).

Most (41\%) patients were found to have single-vessel disease, and two- and three-vessel disease was identified in $33 \%$ and $26 \%$ of patients, respectively. Involvement of the left main (LM) coronary artery (either isolated or combined with other lesions) was found in $8.5 \%$ of patients. The infarct-related artery was most commonly the left anterior descending artery (in approx. 39\% of cases), followed by the right coronary artery (approx. 26\%), left circumflex artery (LCx) (approx. 12\%), diagonal, marginal, or intermediate branch (overall $18 \%$ of cases), LM (3\%), and a surgical graft (2\%).

Significant coronary atherosclerotic lesions were found to be more common in older patients, those with a history of $\mathrm{MI}$, chest pain before cardiac arrest, ST elevation in ECG recorded after ROSC, higher high-sensitivity troponin T levels 


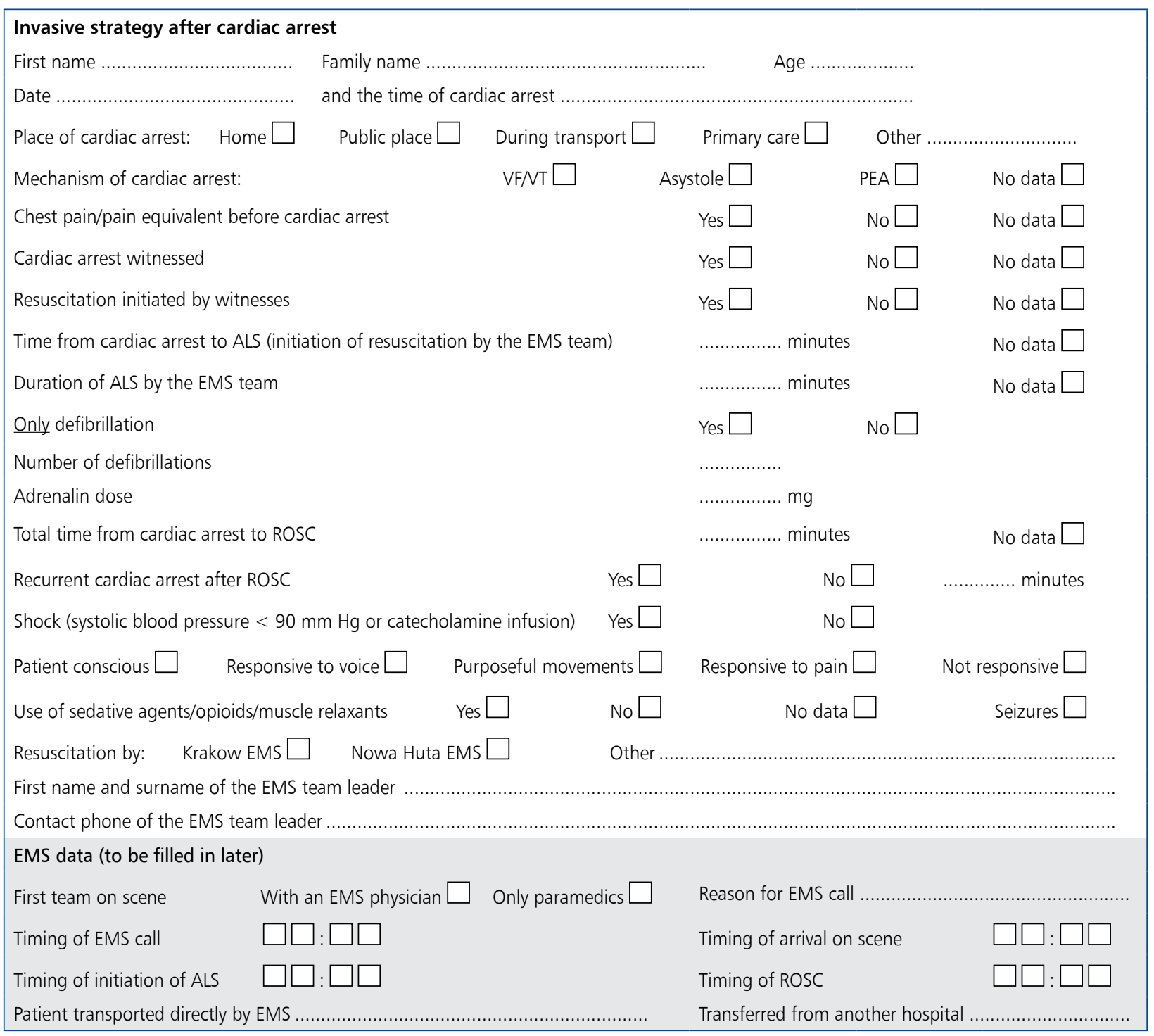

Figure 2. Cardiac arrest patient form; ALS - advanced life support; EMS - emergency medical services; ROSC — return of spontaneous circulation; VFNT — ventricular fibrillation/ventricular tachycardia; PEA — pulseless electrical activity

on admission, and higher peak levels of all markers of myocardial necrosis (i.e., troponin I, troponin T, creatine kinase, and its $\mathrm{MB}$ isoenzyme) during hospitalisation. In contrast, significant coronary atherosclerotic lesions were found to be less common if left bundle branch block was identified in ECG recorded after ROSC (Table 3).

Multivariate analysis identified the following significant predictors of significant coronary atherosclerotic lesions in patients after cardiac arrest: a history of $\mathrm{MI}$, chest pain before cardiac arrest, ST elevation in ECG recorded after ROSC, and older age (Table 4).

As the mere presence of significant coronary atherosclerotic lesions does not equate to the diagnosis of ACS, a similar multivariate analysis was performed to identify predictors of an acute vessel occlusion or a critical stenosis (> 90\%). The only significant predictors of an acute vessel occlusion or a critical coronary stenosis were chest pain before cardiac arrest (relative risk [RR] 2.09, 95\% confidence interval [CI] 1.37-3.19) and ST elevation in ECG recorded after ROSC (RR 1.56, 95\% Cl 1.02-2.38).

An ACS was the final diagnosis in $82 \%$ of patients $(75 \%$ STEMI, 25\% non-STEMI [NSTEMI]), other cardiac cause of cardiac arrest (most commonly ischaemic cardiomyopathy) was diagnosed in $13 \%$ of patients, and a non-cardiac or unknown cause was diagnosed in 5\% of patients (Fig. 6).

Primary coronary intervention $(\mathrm{PCl})$ was performed in $90 \%$ of patients with the diagnosis of ACS, and coronary artery bypass grafting was performed in additional $4 \%$ of patients. PCI was successful (TIMI 3 flow, resolution of ST segments changes and no significant residual stenosis) in 


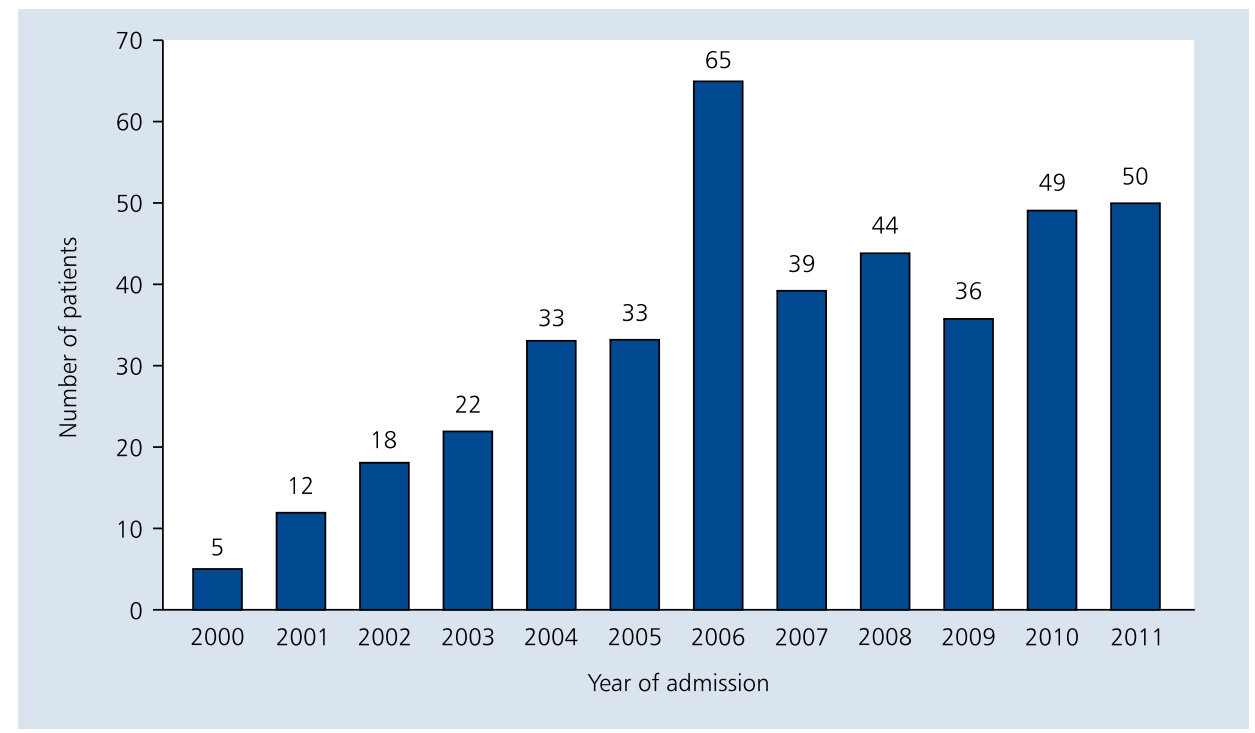

Figure 3. Number of post-cardiac arrest patients admitted to Centre of Invasive Cardiovascular Treatment (CILChSiN, Centrum Interwencyjnego Leczenia Chorób Serca i Naczyń) in 2001-2012

Table 2. Clinical data, circumstances of cardiac arrest, and patient status on admission

\begin{tabular}{|lc|}
\hline Age [years] & $61(20-85)$ \\
Men & $81 \%$ \\
Previous MI & $27 \%$ \\
Previous PCI or CABG & $12 \%$ \\
Diabetes & $19 \%$ \\
Hypertension & $56 \%$ \\
Obesity & $24 \%$ \\
Smoking & $35 \%$ \\
Mechanism of CA: & \\
VFNT & $78 \%$ \\
Asystole & $13 \%$ \\
PEA & $3 \%$ \\
Unknown & $6.69(1.0-30.0)$ \\
CA witnessed by medical personnel & 26.7 \\
CA at home & $11.0-126.0)$ \\
CA in a public place & $11 \%$ \\
Defibrillation-only CPR & $29 \%$ \\
BLS by witnesses & $36 \%$ \\
Time to ALS [min] & $20 \%$ \\
CS during hospitalisation & $18 \%$ \\
\hline
\end{tabular}

ALS - advanced life support; BLS — basic life support; CA — cardiac arrest; CABG — coronary artery bypass grafting; CPR — cardiopulmonary resuscitation; $\mathrm{CS}$ - cardiogenic shock; $\mathrm{MI}$ - myocardial infarction; $\mathrm{PCl}$ - percutaneous coronary intervention; PEA — pulseless electrical activity; ROSC — return of spontaneous circulation; VF — ventricular fibrillation; VT — ventricular tachycardia
$70 \%$ of patients, and TIMI 3 flow was obtained in $76 \%$ of patients. Overall survival to hospital discharge was 63\%, and survival with good neurological outcome at discharge was $49 \%$. In the subset of patients who were unconscious on admission, these survival rates were $52 \%$ and $33 \%$, respectively (Fig. 7).

Overall long-term survival (more than 10 years of follow-up of patients admitted in 2000) was 49\%, and long-term survival in good neurological condition was $42 \%$ ( $87 \%$ among those who survived). Long-term mortality was higher among those discharged in poor neurological condition than those discharged in good condition (45\% vs. $15 \%$, $\mathrm{p}=0.0204$ ) (Fig. 8).

In addition, the estimated rates of major adverse cardiovascular events during long-term follow-up of patients after cardiac arrest were as follows: recurrent cardiac arrest: 11.9\%, cardiovascular death: $7.5 \%, \mathrm{MI}: 7 \%$, stroke: $5.8 \%$, and the overall rate of cardiac arrest, cardiovascular death, $\mathrm{MI}$, and stroke was $20.4 \%$. An ICD was implanted for secondary prevention of SCD in $22.7 \%$ of patients.

To evaluate the primary endpoint of the study, we assessed the effect of various clinical, ECG, angiographic, and laboratory variables on survival with good neurological outcome at discharge.

Variables that were associated with an increased likelihood of good neurological outcome included cardiac arrest mechanism amenable to defibrillation, cardiac arrest witnessed by healthcare personnel, immediate initiation of basic life support by witnesses of cardiac arrests, preserved consciousness and pupil reactions on admission, single-vessel disease, higher peak left ventricular ejection fraction, and successful coronary angioplasty. Variables that were associated 


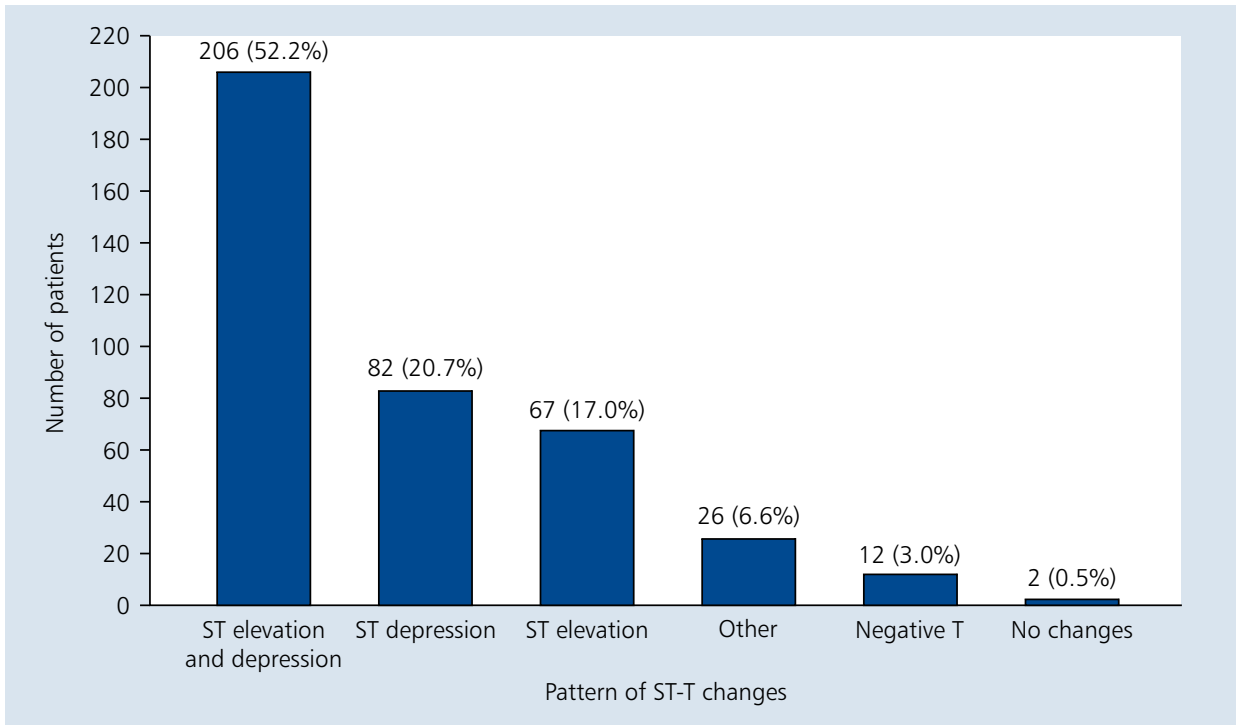

Figure 4. ST-T changes in electrocardiogram recorded after return of spontaneous circulation in post-cardiac arrest patients

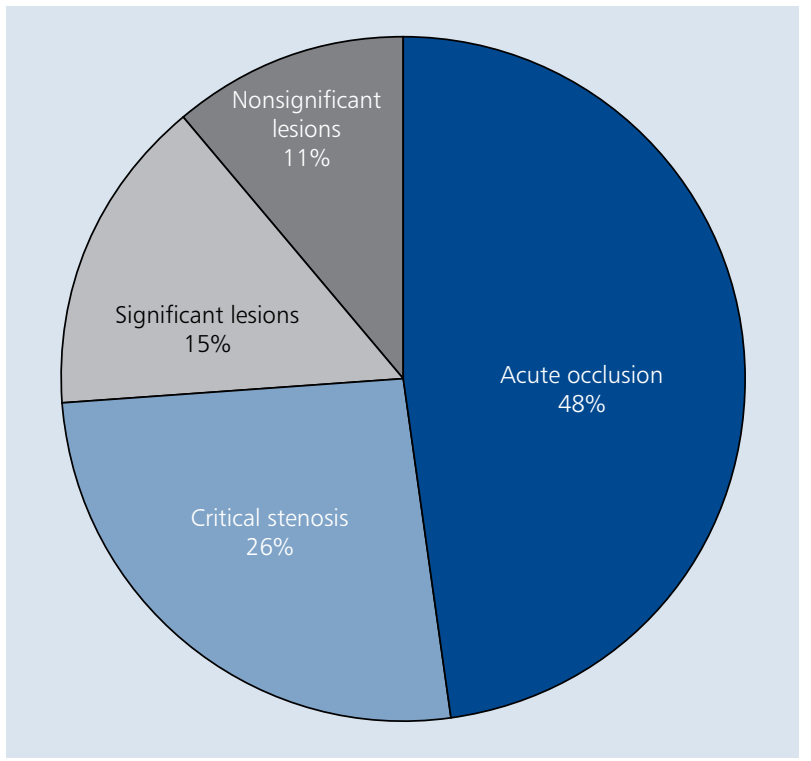

Figure 5. Severity of coronary atherosclerotic lesions in post-cardiac arrest patients

with a reduced likelihood of good neurological outcome included longer time to EMS team arrival on scene, longer duration of resuscitation, longer time to ROSC, diabetes, higher blood glucose and lactate levels on admission, higher peak troponin level, leukocyte count, and body temperature, cardiogenic shock after ROSC or during hospitalisation, and development of renal failure or pneumonia (Table 5).

Multivariate analysis showed that independent predictors of good neurological outcome after cardiac arrest included preserved consciousness on admission, cardiac arrest mechanism amenable to defibrillation, cardiac arrest

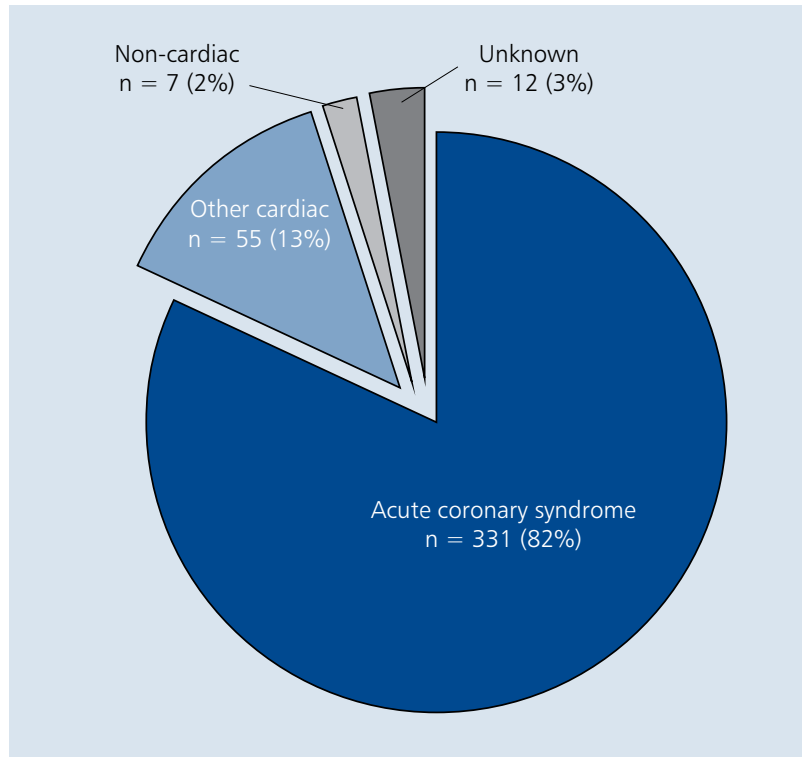

Figure 6. Final diagnosis of the cause of cardiac arrest (CA) in patients admitted for urgent coronary angiography after CA

witnessed by healthcare personnel, absence of cardiogenic shock, and preserved renal function (glomerular filtration rate $>60 \mathrm{~mL} / \mathrm{min} / 1.73 \mathrm{~m}^{2}$ as estimated using the Modification of Diet in Renal Disease [MDRD] formula) (Table 6).

A similar analysis was performed for the secondary endpoint of survival until hospital discharge regardless of the neurological outcome. Independent predictors of survival included preserved consciousness on admission, cardiac arrest mechanism amenable to defibrillation, successful coronary angioplasty, absence of cardiogenic shock, and preserved renal function (Table 7). 
Table 3. Association between various clinical parameters and the presence of significant atherosclerotic lesions in coronary angiography in patients after cardiac arrest — univariate analysis

\begin{tabular}{|c|c|c|c|}
\hline Parameter & Nonsignificant stenoses $(n=47)$ & Significant stenoses $(n=353)$ & $\mathbf{P}$ \\
\hline Mean age [years] & $54.8 \%$ & $61.5 \%$ & 0.000 \\
\hline Male gender & $37(78.7 \%)$ & $289(81.9 \%)$ & 0.6 \\
\hline Hypertension & $26(56.5 \%)$ & $196(56.1 \%)$ & 0.96 \\
\hline Diabetes & $7(15.2 \%)$ & $69(19.8 \%)$ & 0.45 \\
\hline Hypercholesterolaemia & $23(50 \%)$ & $201(57.9 \%)$ & 0.3 \\
\hline Obesity & $10(27 \%)$ & $68(23.8 \%)$ & 0.67 \\
\hline Smoking & $14(70 \%)$ & $113(64.2 \%)$ & 0.6 \\
\hline Coronary artery disease & $15(32.6 \%)$ & $155(44.2 \%)$ & 0.14 \\
\hline Previous MI & $7(15.2 \%)$ & $100(28.5 \%)$ & 0.04 \\
\hline Revascularisation & $3(6.7 \%)$ & $43(12.3 \%)$ & 0.27 \\
\hline Stroke & $3(6.4 \%)$ & $22(6.3 \%)$ & 0.98 \\
\hline Peripheral arterial disease & $3(6.7 \%)$ & $36(10.8 \%)$ & 0.39 \\
\hline VF/VT & $34(77.3 \%)$ & $281(83.8 \%)$ & 0.27 \\
\hline Chest pain & $11(31.4 \%)$ & $202(69.7 \%)$ & 0.000 \\
\hline \multicolumn{4}{|l|}{ ST-T changes: } \\
\hline ST elevation & $16(34 \%)$ & $255(72.2 \%)$ & 0.000 \\
\hline ST depression & $17(37.8 \%)$ & $63(18.2 \%)$ & 0.08 \\
\hline Negative T waves & $1(2.2 \%)$ & $11(3.2 \%)$ & 0.8 \\
\hline Unspecific changes & $10(22.2 \%)$ & $11(3.2 \%)$ & 0.17 \\
\hline \multicolumn{4}{|l|}{ QRS changes: } \\
\hline Normal pattern & $27(60 \%)$ & $230(68 \%)$ & 0.39 \\
\hline LBBB & $9(20 \%)$ & $23(6.8 \%)$ & 0.014 \\
\hline RBBB & $4(8.9 \%)$ & $37(10.9 \%)$ & 0.89 \\
\hline Unspecific & $5(11.1 \%)$ & $48(14.2 \%)$ & 0.84 \\
\hline \multicolumn{4}{|c|}{ Biomarkers on admission, mean: } \\
\hline $\operatorname{Tn}[\mathrm{ng} / \mathrm{mL}]$ & 2.70 & 5.18 & 0.27 \\
\hline hsTnT [ng/mL] & 0.1634 & 0.5564 & 0.032 \\
\hline CK-MB [U/L] & 70.4 & 77.8 & 0.58 \\
\hline CK [U/L] & 544.9 & 646.4 & 0.66 \\
\hline \multicolumn{4}{|l|}{ Peak biomarkers, mean: } \\
\hline Tnl [ng/mL] & 31.70 & 73.24 & 0.004 \\
\hline hsTnT [ng/mL] & 0.071 & 6.784 & 0.017 \\
\hline CK-MB [U/L] & 169.7 & 363.3 & 0.001 \\
\hline CK $[U / L]$ & 2788.9 & 4841.1 & 0.21 \\
\hline
\end{tabular}

CK — creatine kinase; CK-MB — creatine kinase isoenzyme MB; hsTnT — high-sensitivity troponin T; LBBB — left bundle branch block; RBBB — right bundle branch block; $\mathrm{MI}$ — myocardial infarction; Tn — troponin; VF — ventricular fibrillation; VT — ventricular tachycardia

\section{DISCUSSION}

Our findings confirm that coronary artery disease is the most common cause of cardiac arrest among OHCA patients who are admitted for urgent CAG. An acute vessel occlusion was found in nearly half of patients, and a critical stenosis in further $25 \%$ of patients. These results are very similar to those reported by Spaulding et al. [12] who evaluated a population of OHCA patients without a clear non-cardiac cause of cardiac arrest and found an acute occlusion of an epicardial coro- nary artery in $47 \%$ of patients, and significant non-occlusive coronary artery disease in another $24 \%$ of patients. Other authors reported somewhat lower rates of coronary artery disease in populations of OHCA patients. Among patients after OHCA admitted for routine CAG, Anyfantakis et al. [13] found coronary artery occlusion in only about $17 \%$ of patients, and other significant atherosclerotic coronary lesions in about $47 \%$ of patients. MI was diagnosed in only $38 \%$ of cases as for that diagnosis the authors required the presence 
Table 4. Independent predictors of significant coronary atherosclerotic lesions in patients after cardiac arrest — univariate analysis

\begin{tabular}{|lccccc|} 
Variable & Category & N & RR & 95\% Cl & P \\
\hline History of MI & Yes & 109 & 1.84 & $1.08-3.14$ & 0.0241 \\
Chest pain & No & 293 & 1.00 & - & - \\
& Yes & 214 & 2.15 & $1.42-3.26$ & 0.0003 \\
ST elevation & No & 115 & 1.00 & - & - \\
& Yes & 273 & 2.11 & $1.4-3.19$ & -0.0003 \\
Age (per year) & No & 132 & 1.00 & $1.01-1.07$ & - \\
\hline
\end{tabular}

$\mathrm{Cl}$ - confidence interval; $\mathrm{Ml}$ - myocardial infarction; $\mathrm{N}$ - number of patients; $\mathrm{RR}$ - relative risk

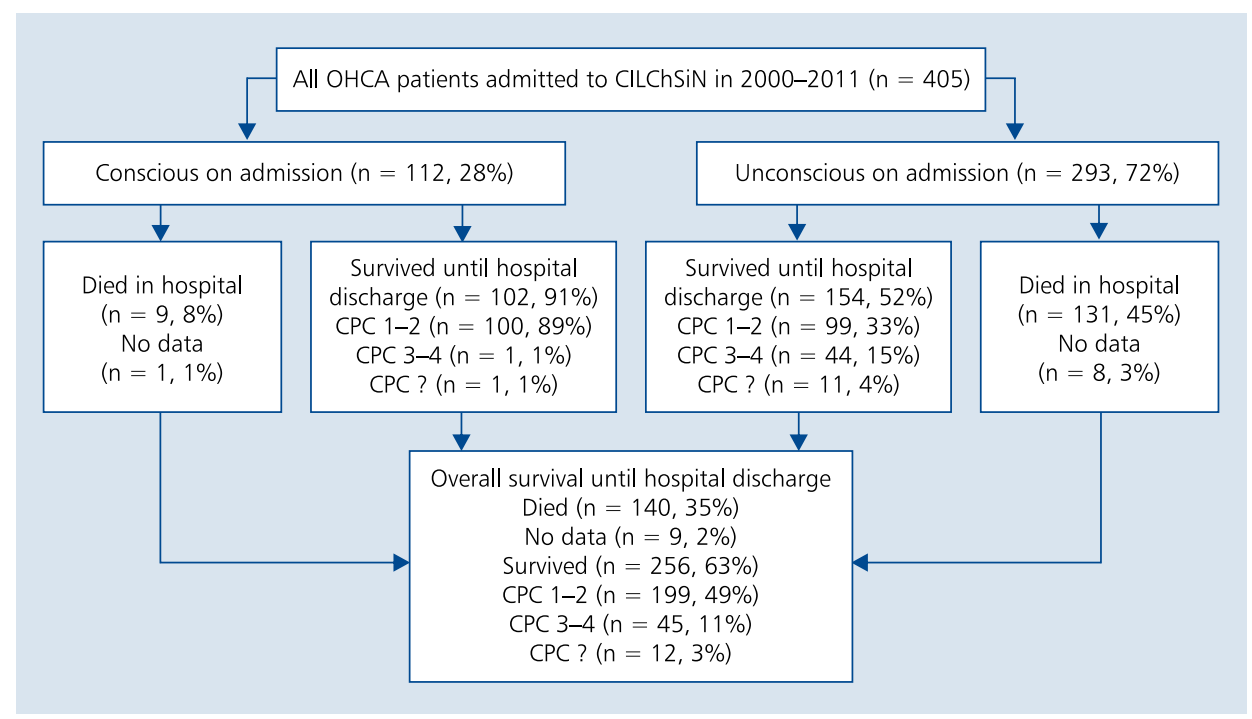

Figure 7. Survival and neurological outcomes in post-cardiac arrest patients at hospital discharge; CILChSiN — Centre of Invasive Cardiovascular Treatment (Centrum Interwencyjnego Leczenia Chorób Serca i Naczyń, John Paul II Hospital, Krakow, Poland: CPC - Cerebral Performance Category, score 1-2 indicates good neurological outcomes; OHCA — out-of-hospital cardiac arrest

of not only a significant but also unstable atherosclerotic lesion. Similarly, Sideris et al. [14] reported that the rate of ACS among patients with OHCA was only about $36 \%$. Thus, it seems that the identification rates of significant and critical coronary lesions and the rates of ACS diagnosed as the cause of cardiac arrest depend mainly on the selected patient admission criteria and the definition of ACS in post-OHCA patients referred for urgent CAG, ranging widely from $30 \%$ to $80 \%$.

The rationale for admitting OHCA patients for invasive CAG is a suspicion of significant coronary atherosclerotic lesions which might be treated invasively. For physicians on duty in cardiac catheterisation laboratories, the major challenge in the everyday clinical practice is thus proper identification of those OHCA patients who require urgent CAG. Our study showed that only older age, a history of $\mathrm{MI}$, the presence of chest pain before cardiac arrest, and ST segment elevation identified in the ECG recorded after ROSC were independent predictors of significant coronary atherosclerotic lesions. The above cited authors found that among numerous potential factors, only chest pain and ST elevation [12] or ST elevation and smoking [13] were independent predictors of significant coronary atherosclerotic lesions and the diagnosis of $\mathrm{Ml}$ in their studies. Thus, the presence of these characteristics might argue for admitting the OHCA patient for urgent CAG.

The major goal of performing coronary angioplasty in OHCA patients is to improve their prognosis. In patients after cardiac arrest, however, improving higher neurological functions seems to be a more important goal that just patient survival, and thus the ultimate goal is survival with good neurological outcome. In our study, survival with good neurological outcome was more frequent among those patients who underwent successful coronary angioplasty compared to those without angioplasty success ( $58 \%$ vs. $42 \%$, p = 0.029), but in multivariate analysis, successful angioplasty was not an independent predictor of good neurological outcome. In contrast, significant independent predictors of good neurological outcome were preserved consciousness on admission, cardiac arrest witnessed by healthcare personnel, cardiac 


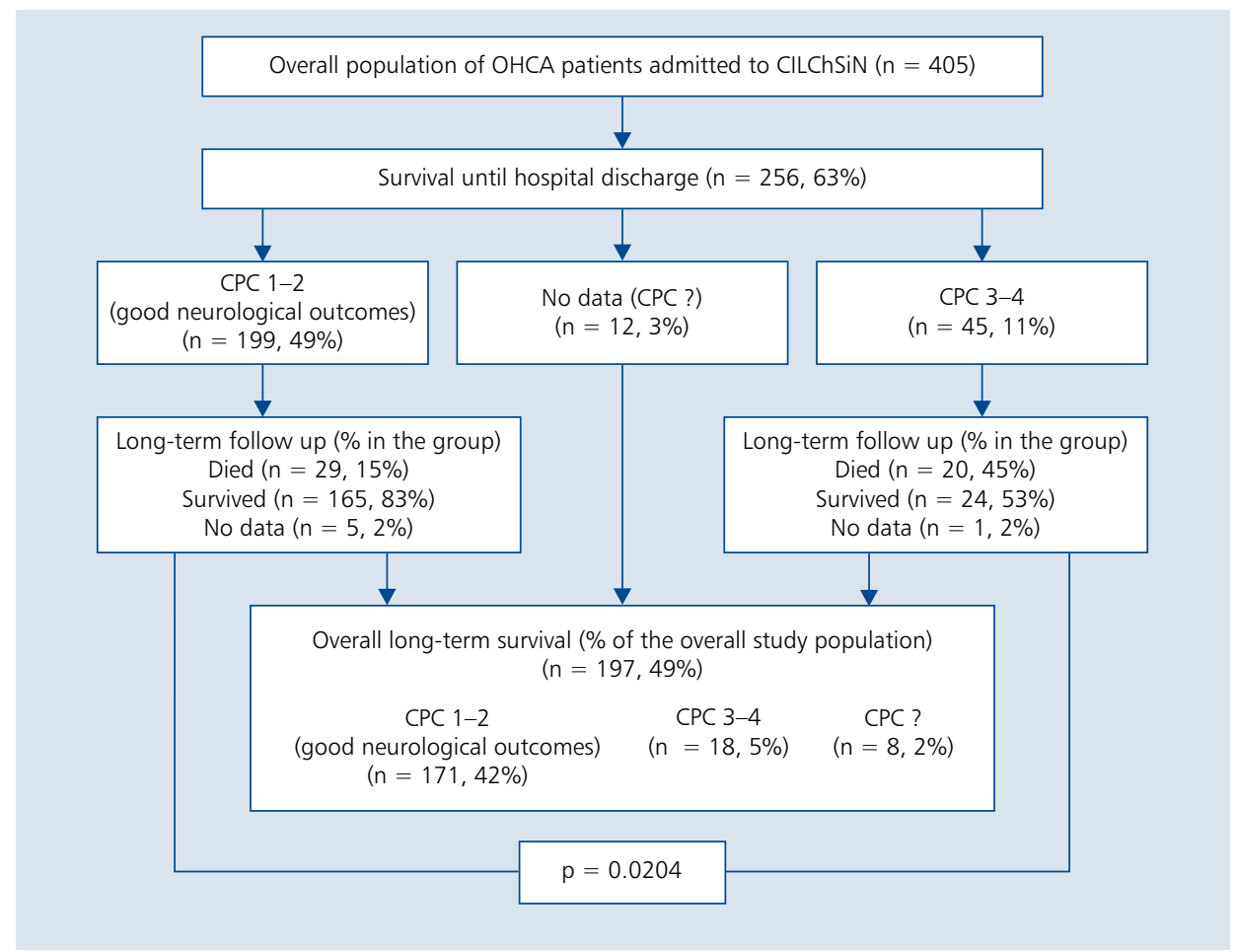

Figure 8. Long-term survival and neurological outcomes in post-cardiac arrest patients; CILChSiN — Centre of Invasive Cardiovascular Treatment (Centrum Interwencyjnego Leczenia Chorób Serca i Naczyń, John Paul II Hospital, Krakow, Poland; CPC — Cerebral Performance Category, score 1-2 indicates good neurological outcomes; OHCA — out-of-hospital cardiac arrest

arrest mechanism amenable to defibrillation, absence of cardiogenic shock, and preserved renal function. However, when we analysed the effect of numerous variables on survival regardless of neurological outcome, successful coronary angioplasty was shown to increase the likelihood of survival until hospital discharge (RR 3.0, 95\% Cl 1.38-6.58, $\mathrm{p}=0.0057$ ). It may be thus speculated that prehospital factors such as immediate initiation of chest compression and cardiac arrest mechanism amenable to defibrillation may be of prime importance for brain function following ROSC. Most data available in the literature (observational studies, retrospective analyses, and patient series) indicate improved survival of cardiac arrest patients in whom successful coronary angioplasty was performed regardless of the changes seen in ECG [15-17]. Only few authors were unable to show survival improvement associated with urgent coronary angioplasty in patients after cardiac arrest. Despite that, most of these authors recommended an invasive strategy in patients after cardiac arrest in whom MI is suspected $[18,19]$. With current knowledge, it cannot be unequivocally determined whether $\mathrm{PCl}$ in patients after cardiac arrest is an independent factor that improves survival and neurological outcomes. It would be necessary but ethically questionable to perform a randomised study in which post-cardiac arrest patients with likely cardiac aetiology of the event would be assigned to early interventional or medical management. It should also be noted that although the ESC guidelines recommend immediate invasive CAG in post-cardiac arrest patients with ST segment elevation (class of recommendation I, level of evidence B) and only suggest such an approach in patients without ST elevation in whom ACS is suspected (class of recommendation Ila, level of evidence B), our study did not show any difference in outcomes, including both survival and neurological condition, between STEMI and NSTEMI patients.

\section{Limitations of the study}

Major limitations of our study include its retrospective and observational nature. The study was largely based on information retrieved from patient medical records, without any possibility of direct data verification. Regarding the prehospital period, data were often lacking on the circumstances of cardiac arrest and undertaken resuscitation procedures. In the prospectively evaluated patient subset, although information on the duration of resuscitation was collected directly from the EMS team involved, the obtained data were often subjective and not based on any objective measurements. Another obvious weakness of the study has been the fact that patients were selected for urgent invasive CAG by a physician on duty in the cardiac catheterisation laboratory. For obvious reasons, no randomisation was possible in these circumstances. Also, no formal criteria were used regarding which post-cardiac arrest patients should be admitted and which should not. The 
Table 5. Relation between various parameters and good neurological outcomes in patients after cardiac arrest — univariate analysis

\begin{tabular}{|c|c|c|c|c|c|}
\hline Variable & Category & $\mathbf{N}$ & $\mathbf{R R}$ & $95 \% \mathrm{Cl}$ & $\mathbf{P}$ \\
\hline Age & - & 405 & 0.961 & $0.944-0.979$ & 0.0000 \\
\hline \multirow[t]{2}{*}{ Gender } & Men & 329 & 1.0 & - & - \\
\hline & Women & 76 & 0.799 & $0.481-1.328$ & 0.3864 \\
\hline \multirow[t]{2}{*}{ Diabetes } & No & 321 & 1.0 & - & - \\
\hline & Yes & 78 & 0.533 & $0.321-0.885$ & 0.0151 \\
\hline \multirow[t]{2}{*}{ Previous MI } & No & 293 & 1.0 & - & - \\
\hline & Yes & 109 & 0.768 & $0.492-1.199$ & 0.2455 \\
\hline \multirow[t]{2}{*}{ Previous revascularisation } & No & 352 & 1.0 & - & - \\
\hline & Yes & 47 & 0.790 & $0.424-1.475$ & 0.4600 \\
\hline \multirow[t]{2}{*}{ Mechanism of cardiac arrest } & Non-DEF & 66 & 1.0 & - & - \\
\hline & DEF & 316 & 6.684 & $3.423-13.049$ & 0.0000 \\
\hline \multirow[t]{3}{*}{ Place of cardiac arrest } & Home & 131 & 1.0 & - & - \\
\hline & PUB & 74 & 1.317 & $0.713-2.432$ & 0.3776 \\
\hline & MED & 162 & 6.199 & $3.678-10.447$ & 0.0000 \\
\hline \multirow[t]{3}{*}{ Life support by cardiac arrest witnesses } & No & 41 & 1.0 & - & - \\
\hline & BLS & 111 & 3.465 & $1.514-7.926$ & 0.0003 \\
\hline & ALS & 165 & 11.564 & $5.096-26.245$ & 0.0000 \\
\hline Time to EMS arrival at scene [min] & - & 310 & 0.882 & $0.841-0.926$ & 0.0000 \\
\hline Duration of ALS [min] & - & & 0.957 & $0.938-0.976$ & 0.0000 \\
\hline Time from cardiac arrest to ROSC [min] & - & 198 & 0.956 & $0.938-0.975$ & 0.0000 \\
\hline \multirow[t]{2}{*}{ State of consciousness on admission } & Unconscious & 293 & 1.0 & - & - \\
\hline & Conscious & 112 & 17.677 & $8.820-35.427$ & 0.0000 \\
\hline \multirow[t]{4}{*}{ Glasgow coma scale } & 3 & 129 & 1.0 & - & - \\
\hline & $4-7$ & 61 & 5.800 & $2.812-11.963$ & 0.0000 \\
\hline & $8-14$ & 27 & 46.000 & $12.43-170.16$ & 0.0000 \\
\hline & 15 & 59 & 171.000 & $38.13-766.82$ & 0.0000 \\
\hline \multirow[t]{2}{*}{ Pupil reactions } & No & 96 & 1.0 & - & - \\
\hline & Yes & 236 & 10.5444 & $5.648-19.686$ & 0.0000 \\
\hline \multirow[t]{4}{*}{ Cause of cardiac arrest } & Non-cardiac & 19 & 1.0 & - & - \\
\hline & Non-ACS & 55 & 1.999 & $0.649-6.154$ & 0.2261 \\
\hline & NSTEMI & 88 & 1.818 & $0.622-5.315$ & 0.2739 \\
\hline & STEMI & 243 & 2.466 & $0.892-6.817$ & 0.0818 \\
\hline \multirow[t]{4}{*}{ n-vessel disease (n-VD) } & $0-V D$ & 43 & 1.0 & - & - \\
\hline & 1-VD [237] & 145 & 1.915 & $1.344-2.728$ & 0.0003 \\
\hline & 2-VD [238] & 118 & 0.836 & $0.428-1.039$ & 0.3452 \\
\hline & $3-V D$ [239] & 92 & 0.749 & $0.370-0.958$ & 0.1744 \\
\hline Syntax score & - & 372 & 0.986 & $0.966-1.007$ & 0.1836 \\
\hline Maximum LVEF [\%] & - & 326 & 1.059 & $1.040-1.079$ & 0.0000 \\
\hline \multirow[t]{2}{*}{ Left bundle branch block } & No & 255 & 1.0 & - & - \\
\hline & Yes & 32 & 0.631 & $0.292-1.362$ & 0.2406 \\
\hline \multirow[t]{2}{*}{ PCl success } & No & 72 & 1.0 & - & - \\
\hline & Yes & 156 & 2.307 & $1.386-3.841$ & 0.0013 \\
\hline Glycaemia & - & & 0.908 & $0.871-0.946$ & 0.0000 \\
\hline Lactates & - & & 0.729 & $0.641-0.829$ & 0.0000 \\
\hline Peak troponin I [ng/mL] & - & & 0.997 & $0.994-0.999$ & 0.0181 \\
\hline
\end{tabular}


Table 5. (cont.) Relation between various parameters and good neurological outcomes in patients after cardiac arrest — univariate analysis

\begin{tabular}{|c|c|c|c|c|c|}
\hline Variable & Category & $\mathbf{N}$ & $\mathbf{R R}$ & $95 \% \mathrm{Cl}$ & $\mathbf{P}$ \\
\hline Duration of $\mathrm{PCl}[\mathrm{min}]$ & - & & 0.991 & $0.979-1.004$ & 0.1601 \\
\hline Peak leukocyte count $\left[\times 10^{3} / \mu \mathrm{L}\right]$ & - & & 0.944 & $0.910-0.979$ & 0.0020 \\
\hline Body temperature on admission & - & & 1.073 & $0.812-1.418$ & 0.6190 \\
\hline Maximum body temperature & - & & 0.465 & $0.385-0.604$ & 0.0000 \\
\hline \multirow[t]{2}{*}{ Shock after ROSC } & No & 361 & 1.0 & - & - \\
\hline & Yes & 44 & 0.151 & $0.065-0.349$ & 0.0000 \\
\hline \multirow[t]{2}{*}{ Shock during hospitalisation } & No & 280 & 1.0 & - & - \\
\hline & Yes & 125 & 0.216 & $0.134-0.347$ & 0.0000 \\
\hline \multirow[t]{2}{*}{ Shock overall } & No & 240 & 1.0 & - & - \\
\hline & Yes & 164 & 0.108 & $0.067-0.173$ & 0.0000 \\
\hline \multirow[t]{2}{*}{ Pneumonia } & No & 255 & 1.0 & - & - \\
\hline & Yes & 126 & 0.340 & $0.216-0.534$ & 0.0000 \\
\hline Renal failure (GFR $<60 \mathrm{~mL} / \mathrm{min}$ & No & 177 & 1.0 & - & - \\
\hline [MDRD formula]) & Yes & 199 & 0.117 & $0.072-0.189$ & 0.0000 \\
\hline \multirow[t]{4}{*}{ GFR $[\mathrm{mL} / \mathrm{min}]$} & $<15$ & 20 & 1.0 & - & - \\
\hline & $15-30$ & 42 & 6.7398 & $0.799-56.878$ & 0.0794 \\
\hline & $30-60$ & 133 & 10.5269 & $1.355-81.792$ & 0.0246 \\
\hline & $>60$ & 155 & 75.3216 & $9.605-590.633$ & 0.0000 \\
\hline Time from cardiac arrest to PCI [h] & - & 205 & 0.999 & $0.998-1.001$ & 0.2440 \\
\hline
\end{tabular}

ACS - acute coronary syndrome; ALS — advanced life support; BLS — basic life support; CI — confidence interval; DEF — amenable to defibrillation; EMS - emergency medical services; GFR — glomerular filtration rate; LVEF — left ventricular ejection fraction; MED — witnessed by medical personnel; MDRD - Modification of Diet in Renal Disease; MI - myocardial infarction; N - number of patients; non-ACS - cardiac but not ACS; non-DEF — not amenable to defibrillation; NSTEMI — non-ST elevation myocardial infarction; PCI — percutaneous coronary intervention; PUB — public place; ROSC — return of spontaneous circulation; RR — relative risk; STEMI — ST elevation myocardial infarction

Table 6. Independent predictors of good neurological outcomes after cardiac arrest — multivariate analysis

\begin{tabular}{|lccccc|}
\hline Variable & Category & N & RR & 95\% Cl & P \\
\hline State of consciousness & Unconscious & 293 & 1.0 & - & - \\
& Conscious & 112 & 3.260 & $1.404-7.572$ & 0.0060 \\
Mechanism of cardiac arrest & Non-DEF & 66 & 1.0 & - & - \\
\multirow{2}{*}{ Place of cardiac arrest } & DEF & 316 & 2.457 & $1.172-5.153$ & 0.0173 \\
& Non-MED & 205 & 1.0 & - & - \\
Shock & MED & 162 & 2.166 & $1.207-3.884$ & 0.0095 \\
\multirow{2}{*}{ Renal failure } & No & 240 & 1.0 & - & - \\
& Yes & 164 & 0.453 & $0.255-0.806$ & 0.0071 \\
& No & 177 & 1.0 & - & - \\
\hline
\end{tabular}

$\mathrm{Cl}$ — confidence interval; DEF — amenable to defibrillation; MED — witnessed by medical personnel; N — number of patients; RR — relative risk

decision whether to admit was solely at the discretion of the involved physician and depended on his or her judgment of the likelihood that cardiac arrest was due to a cardiac cause. Also of note, cardiac arrest was witnessed by healthcare personnel in as many as $44 \%$ of patients. Such a high proportion of medically witnessed cardiac arrests, i.e. occurring in circumstances favouring immediate resuscitation efforts, was due to the fact that very often the EMS team was dispatched to a patient with chest pain, and cardiac arrest occurred after the EMS team arrived on scene or during patient transport to the hospital. This has undoubtedly affected our results as immediate resuscitation is a known factor favouring good 
Table 7. Independent predictors of survival until hospital discharge in patients after cardiac arrest regardless of their neurological status - multivariate analysis

\begin{tabular}{lccccc} 
Variable & Category & N & RR & 95\% Cl & P \\
\hline State of consciousness & Unconscious & 293 & 1.0 & - & - \\
& Conscious & 112 & 6.910 & $2.409-19.817$ & 0.0003 \\
Mechanism of cardiac arrest & Non-DEF & 66 & 1.0 & - & - \\
& DEF & 316 & 4.287 & $1.828-10.054$ & 0.0008 \\
PCl success & No & 72 & 1.0 & - & - \\
& Yes & 156 & 3.011 & $1.378-6.580$ & 0.0057 \\
Shock & No & 240 & 1.0 & - & - \\
\multirow{2}{*}{ Renal failure } & Yes & 164 & 0.335 & $0.153-0.732$ & 0.0061 \\
& No & 177 & 1.0 & - & - \\
\hline
\end{tabular}

$\mathrm{Cl}$ - confidence interval; $\mathrm{DEF}$ - amenable to defibrillation; $\mathrm{N}$ - number of patients; $\mathrm{PCl}$ - percutaneous coronary intervention; $\mathrm{RR}$ - relative risk

outcomes, and at the same time it makes it more difficult to generalise our findings to the whole population of OHCA patients. It should also be noted that the studied OHCA patients were not subjected to mild therapeutic hypothermia (except for few patients near the end of the study period) which was introduced in CILChSiN since September 2011, and is an intervention shown in randomised studies to improve neurological function in post-cardiac arrest patients.

\section{CONCLUSIONS}

1. Patients with cardiac arrest preceded by chest pain, with a history of MI, with ST segment elevation, who are in old age, or with other clinical data suggesting ACS should be transferred directly to cardiac catheterisation laboratories.

2. Successful coronary angioplasty in patients after cardiac arrest increases their likelihood to survive.

3. Successful coronary angioplasty in patients after cardiac arrest does not predict good neurological outcomes at hospital discharge.

\section{Conflict of interest: none declared}

\section{References}

1. Roger VL, Go AS, Lloyd-Jones DM et al. Executive summary: hear disease and stroke statistics: 2012 update: a report from the American Heart Association. Circulation, 2012; 125: 188-197.

2. Atwood C, Eisenberg MS, Herlitz J, Rea TD. Incidence of EMS-treated out-of-hospital cardiac arrest in Europe. Resuscitation, 2005; 67: 75-80.

3. Zipes DP, Priori SG. Sudden cardiac death. A hanbook for clinical practice. Blackwell Publishing, Malden, Oxford, Carlton 2006.

4. Rudner R, Jalowiecki P, Karpel E, Dziurdzik P, Alberski B, Kawecki P. Survival after out-of-hospital cardiac arrests in Katowice (Poland): outcome report according to the "Utstein style". Resuscitation, 2004; 61: 315-325.

5. Nolan JP, Soar J, Zideman DA et al. European Resuscitation Council Guidelines for Resuscitation 2010 Section 1. Executive summary. Resuscitation, 2010; 81: 1219-1276.

6. Nolan JP, Neumar RW, Adrie C et al. Post-cardiac arrest syndrome: epidemiology, pathophysiology, treatment, and prognostication. A Scientific Statement from the International Liaison Committee on Resuscitation; the American Heart Association Emergency Cardiovascular Care Committee; the Council on Cardiovascular Surgery and Anesthesia; the Council on
Cardiopulmonary, Perioperative, and Critical Care; the Council on Clinical Cardiology; the Council on Stroke. Resuscitation, 2008; 79: 350-379.

7. Noc M. Urgent coronary angiography and percutaneous coronary intervention as a part of postresuscitation management. Crit Care Med, 2008; 36: S454-S457.

8. Steg PG, James SK, Atar D et al. ESC Guidelines for the management of acute myocardial infarction in patients presenting with ST-segment elevation: the Task Force on the management of ST-segment elevation acute myocardial infarction of the European Society of Cardiology (ESC). Eur Heart J, 2012; 33: 2569-2619.

9. Cummins RO, Chamberlain DA, Abramson NS et al. Recommended guidelines for uniform reporting of data from out-of-hospital cardiac arrest: the Utstein Style. A statement for health professionals from a task force of the American Heart Association, the European Resuscitation Council, the Heart and Stroke Foundation of Canada, and the Australian Resuscitation Council. Circulation, 1991; 84: 960-975.

10. Wijns W, Kolh P, Danchin N, et al. Guidelines on myocardial revascularization. Eur Heart J, 2010; 31: 2501-2555.

11. Sheehan FH, Braunwald E, Canner P et al. The effect of intravenous thrombolytic therapy on left ventricular function: a report on tissue-type plasminogen activator and streptokinase from the Thrombolysis in Myocardial Infarction (TIMI Phase I) trial. Circulation, 1987; 75: 817-829.

12. Spaulding CM, Joly LM, Rosenberg A et al. Immediate coronary angiography in survivors of out-of-hospital cardiac arrest. N Engl J Med, 1997; 336: 1629-1633.

13. Anyfantakis ZA, Baron G, Aubry P et al. Acute coronary angiographic findings in survivors of out-of-hospital cardiac arrest. Am Heart J, 2009; 157: 312-318.

14. Sideris G, Voicu S, Dillinger JG et al. Value of post-resuscitation electrocardiogram in the diagnosis of acute myocardial infarction in out-of-hospital cardiac arrest patients. Resuscitation, 2011; 82: 1148-1153.

15. Dumas F, Cariou A, Manzo-Silberman S et al. Immediate percutaneous coronary intervention is associated with better survival after out-of-hospital cardiac arrest: insights from the PROCAT (Parisian Region Out of hospital Cardiac ArresT) registry. Circ Cardiovasc Interv, 2010; 3: 200-207.

16. Gorjup V, Radsel P, Kocjancic ST et al. Acute ST-elevation myocardial infarction after successful cardiopulmonary resuscitation. Resuscitation, 2007; 72: 379-385.

17. Reynolds JC, Callaway CW, El Khoudary SR et al. Coronary angiography predicts improved outcome following cardiac arrest: propensity-adjusted analysis. J Intensive Care Med, 2009; 24: 179-186.

18. Lettieri C, Savonitto S, De Servi S et al. Emergency percutaneous coronary intervention in patients with ST-elevation myocardial infarction complicated by out-of-hospital cardiac arrest: early and medium-term outcome. Am Heart J, 2009; 157: 569-75e1.

19. Garot P, Lefevre T, Eltchaninoff $\mathrm{H}$ et al. Six-month outcome of emergency percutaneous coronary intervention in resuscitated patients after cardiac arrest complicating ST-elevation myocardial infarction. Circulation, 2007; 115: $1354-1362$ 


\title{
Wyniki leczenia inwazyjnego u pacjentów po nagłym zatrzymaniu krążenia: 10 lat doświadczeń centrum kardiologii interwencyjnej
}

\author{
Aleksander Zeliaś ${ }^{1}$, Janina Stępińska², Janusz Andres ${ }^{3}$, Aleksander Trąbka-Zawicki ${ }^{1}$, Jerzy Sadowski ${ }^{4}$, \\ Krzysztof Żmudka ${ }^{1}$
}

${ }^{1}$ Klinika Kardiologii Interwencyjnej, Instytut Kardiologii, Uniwersytet Jagielloński, Collegium Medicum,

Szpital im. Jana Pawła II w Krakowie, Kraków

${ }^{2}$ Klinika Intensywnej Terapii Kardiologicznej, Instytut Kardiologii, Warszawa

${ }^{3}$ Katedra Anestezjologii i Intensywnej Terapii, Uniwersytet Jagielloński, Collegium Medicum, Kraków

${ }^{4}$ Klinika Chirurgii Serca, Naczyń i Transplantologii, Instytut Kardiologii, Uniwersytet Jagielloński, Collegium Medicum,

Szpital im. Jana Pawła II w Krakowie, Kraków

\section{Streszczen ie}

Wstęp i cel: Celem pracy była ocena wyników leczenia interwencyjnego pacjentów po nagłym zatrzymaniu krążenia (NZK) pozaszpitalnym o prawdopodobnie wieńcowej etiologii, przyjmowanych do pilnej diagnostyki inwazyjnej naczyń wieńcowych. Metody: Retrospektywną (2000-2010) i prospektywną (2010-2011) analizą objęto dane medyczne chorych po NZK pozaszpitalnym przyjmowanych do centrum kardiologii interwencyjnej. Chorzy stanowiący populację badaną nie byli (z wyjątkiem kilku pacjentów pod koniec okresu obserwacji) poddawani łagodnej hipotermii terapeutycznej, która została wprowadzona w centrum kardiologii inwazyjnej dopiero od 1.09.2011 r. Analizie poddano okoliczności NZK i przebieg resuscytacji, dane demograficzne oraz przeszłość chorobową pacjentów, zapis EKG po przywróceniu tętna (ROSC), wyniki koronarografii oraz angioplastyki, wyniki badania echokardiograficznego i EKG po interwencji wieńcowej, przebieg i komplikacje występujące w trakcie hospitalizacji oraz przeżycie i stan neurologiczny w momencie wypisu ze szpitala, a także w obserwacji odległej.

Wyniki: W analizowanym okresie przyjęto 405 chorych po NZK, 340 w grupie retrospektywnej i 65 w grupie prospektywnej. Średni wiek pacjentów wyniósł 61 lat. 81\% stanowili mężczyźni, u 78\% stwierdzono migotanie komór lub częstoskurcz komorowy jako mechanizm NZK, 70\% chorych było nieprzytomnych, a u 11\% zaobserwowano wstrząs kardiogenny w chwili przyjęcia. Średni czas od NZK do ROSC wyniósł 26,7 min. W koronarografii u 48\% osób wstępowała świeża okluzja tętnicy wieńcowej, a u 26\% pacjentów stwierdzano zwężenia krytyczne. Ostatecznie ostry zespół wieńcowy (OZW) jako przyczynę NZK rozpoznano u 82\% chorych (STEMI 75\%, NSTEMI 25\%), drugą najczęstszą przyczyną była kardiomiopatia niedokrwienna. Angioplastykę wieńcową wykonano u 90\% chorych z OZW, a pomostownie aortalno-wieńcowe u 4\% osób. Angioplastyka zakończyła się sukcesem u 70\% pacjentów. Przeżycie do wypisu ze szpitala w całej grupie wyniosło 63\%, a przeżycie w korzystnym stanie neurologicznym odnotowano u 49\% pacjentów. W grupie chorych wyjściowo nieprzytomnych przeżycie i dobry stan neurologiczny zaobserwowano odpowiednio u 52\% i 33\% osób. W trakcie obserwacji odległej (do 12 lat po NZK) 49\% pacjentów przeżyło, a $42 \%$ było w dobrym stanie neurologicznym (87\% chorych, którzy przeżyli). Niezależnymi czynnikami decydującymi o przeżyciu w dobrym stanie neurologicznym były: zachowany stan przytomności w chwili przyjęcia, mechanizm defibrylacyjny NZK, zatrzymanie krążenia w obecności personelu medycznego, brak wstrząsu kardiogennego i zachowana funkcja nerek. Skuteczna angioplastyka wieńcowa wiązała się z poprawą przeżycia do wypisu ze szpitala, jeżeli nie uwzględniano stanu neurologicznego chorych.

Wnioski: Najważniejszą przyczyną pozaszpitalnego NZK jest choroba wieńcowa, a zwłaszcza ostre zespoły wieńcowe. Koronarografia i angioplastyka wieńcowa są ważnymi elementami właściwej opieki poresuscytacyjnej, ponieważ mogą poprawiać przeżywalność chorych po NZK, choć ich wpływ na osiągany stan neurologiczny pozostaje niejasny.

Słowa kluczowe: nagłe zatrzymanie krążenia, koronarografia, angioplastyka wieńcowa, przeżycie, rokowanie neurologiczne

Kardiol Pol 2014; 72, 8: 687-699

\section{Adres do korespondencji:}

dr n. med. Aleksander Zeliaś, Klinika Kardiologii Interwencyjnej, Instytut Kardiologii, Uniwersytet Jagielloński, Collegium Medicum, Szpital im. Jana Pawła II w Krakowie, ul. Prądnicka 80, 31-202 Kraków, e-mail: aazelias@gmail.com
Praca wpłynęła: 02.11.2013 r.
Zaakceptowana do druku: 13.02.2014 r.
Data publikacji AoP: 01.04.2014 r. 